\title{
要介助者の居住する戸建て住宅における便所設計の調査 PLANNING RESEARCH OF TOILETS IN DETACHED HOUSING FOR PERSONS RECEIVING CARE
}

\author{
後藤 義 明*, 田中真二**, 小野英哲 $* * *$ \\ Yoshiaki GOTO, Shinji TANAKA and Hidenori ONO
}

\begin{abstract}
We have investigated 169 samples of toilets in individual housing where people with disabilities have lived, built since 1995. Results indicate some features of toilets for use by persons who need care, about shape, area, space for assisting, and other uses of toilets.

We devised plans of toilets for persons receiving care into nine types according to the ways of connection between toilet and other rooms. Half of the samples have only one entrance door to a corridor. In Japan, it's not usual that there is a toilet in the bedroom. But in this research there were 60 or more toilets connecting to the bedroom and to the bathroom etc. for their convenience. Especially, if they set a ceiling hoist for mobility, they made a connective toilet to the bathroom and bedroom.
\end{abstract}

KeyWords: movement, disability, barrier-free, housing, toilet, care

動作，身体障害、バリアフリー、住宅、便所、介助

1.はじめに

我が国では来るべき超高齢社会に備えるために様々な分野で社会 システムの整備が急がれている。2000年 4 月、介護保険法と住 宅の品質確保の促進等に関する法律（以下；品確法）がともに施行 された。この二つの法律は、個人住宅で老後の生活をスムースに送 るために必要とされる住宅の構造に関わる内容が盛り込まれてい る。介護保険法では介助が必要となった時の住宅改良の範囲と費用 を、また後者の品確法では、新築時に介助を見越して行うべき設計 配慮について定められた。品確法で制定された日本住宅性能基準に 含まれる高齢者等への配慮に関する性能では、「安全と移動の容易 性を保つための配慮を考えて評価方法を定めている」1とされてい る。ここでいう安全性は主に移動に関わるものであるが、身体機能 が低下した場合に生じる制約を考慮して、自立生活のしやすさだけ でなく、介助のしやすさも視点にいれている。そして、基本的な生 活行為であり、かつ、人間の尊厳を守るためにできるだ自分の力 で行うべき排泄のための空間としての便所に関しては、腰掛け（洋 式）便器の採用と手すりの設置、便所の大きさ及び出入り口の通過 寸法を定めている。便所の大きさは排泄時に被介助者に対して前方 と側方から介助できることとして、壁内法寸法の最小值を短い辺の 方で $1300 \mathrm{~mm}$ としている(注1。一般的な洋式便器を用いた場合に、こ
の最小寸法は便器前端あるいは側端から壁までの距離が $500 \mathrm{~mm}$ 以上 確保されることを考慮して決められている。

便所の内での排泄に関わる行為は、便器接近・脱衣・便器着座（排 泄位圈に着く) ・排泄・後始末・便器離座（排泄位置から脱する）・ 着衣・便器洗浄 (水洗便所の場合) ・手洗い・手拭きがあげられる。 順番が異なったり、一部便所の外で行われることもがあるが、これ らの行為それそれに介助の必要性が考えられる。さらには、移動介 助機器等の福祉機器の使用を考慮した計画も要求される。また、便 所内で洗面や洗濯等の排泄以外の行為を行うこともあり、障害を有 する人の便所に求める要求は多種多様である。

筆者らは、便器着座、便器離座 (車いす等と便器間の移乗) 時に 必要なスペースに関する考察ついて計測実験を行い、1998 年に日 本建築学会計画系論文集 (2に発表している。しかしながら、介助を 考慮した便所を計画するための資料整備としでは、移乗動作の最小 寸法の他にも究明すべき課題が多い。

以上のことから、介助を前提とした場合に住宅に求められるさら なる設計手法を確立することが急がれる。そこで、実際に介助が必 要な障害者が居住する住宅に見られる便所の設計事例を調査し、平 面計画上の特性等を分析することで、介助を考慮した便所設計のあ り方に関する基礎的な知見を得たので報告する。
* 東京工業大学 大学院生 (社会人大学院プログラム) 積水八ウス侏生涯住宅研究室

** 積水八ウス侏)生涯住宅研究室

*** 東北工業大学 教授. 工博

東京工業大学 名誉教授
Graduated Student, Tokyo Institute of Technology, Sekisui House Lifelong Housing R\&D Institute

Sekisui House Lifelong Housing R\&D Institute

Prof., Tohoku Institute of Technology, Dr. Eng. 


\section{2. 目的及び調查方法 \\ (1) 目的}

日常生活における身体機能低下を補完するための設計(以下配慮 設計)が施された新築戸建て住宅(以下配慮住宅)における便所の配 慮設計の内容を、障害を有する对象者(以下対象者)の障害の種類、 程度等を考慮してその特致を分析し、新築時における便所の配慮設 計のあり方について基礎的な知見を得る。

\section{(2) 调查方法}

工業化住宅会社 S 社が設計、施工を行った戸建住宅の中から、介 助を必要とする対象者が家族の中に一人だけいる物件を抽出し、調 查対象とした( 総数 169 件)。

対象者の障害の種類、程度及び配虑設計内容等について、担当し た設計者から情報を得た。

また、設計図書（敷地図、各階平面図、仕様書等）より、記載さ れた配虑設計項目及び平面計画の特徵を探り、介助を要する場合の 便所計画の分析を行った。

\section{(3)調查内容}

a. 対象者属性：年齢、性別、症状名、障害の種類、日常生活にお ける介助の程度、使用中の福祉機器等

b。住宅本体の属性：建築地、床面積、階数、竣工年月等

c. 对象者が使用する便所（以下；便所）の平面計画の特徵：大き

さ、形状、他の室との関係、便房内に設けた設備機器等

d. ホームエレベーター、天井走行水平移動介助装置（以下；天井 走行リフト(注2) 等の大型福祉機器の導入状況

\section{3. 単䢁集計結果}

\section{(1)住宅本体の㫳性}

1)竣工年／95 年 1 月から 99 年 12 月の間に竣エしている（表－1）。 2)規模／延床面積は $46 \mathrm{~m} \sim 365 \mathrm{~m}^{2}$ の範囲であった（表－2）。階 数別では平屋建てが 10 件 $(5.9 \%) 、 2$ 階建てが 146 件( $86.4 \%) 、$ 3 階建てが 13 件 $(7.7 \%)$ である（表－3）

3) 大型設備の導入状況／エレベータを装備した住宅は 35 件であ り、そのうち対象者の便所を 2 階以上の階に設定した例が 7 件で あった（表－4）。また、天井走行リフトを装備した住宅は 33 件で、 便器上をレールが通過していて便器までの移動に供する事ができる 例が 23 件、通過しない（すなわち便器へ移動には水平移動装置を 用いない）例が 10 件であった。そのなかには便所を使わないで排 泄する例が 3 件含まれていた（表一 5 ）。

\section{(2)対象者の原性}

1)年齢・性別・障害原因／対象者の年齢及び障害の原因(注 3 となっ た疾病、事故等の内訳を表一6に示す。年路は全世代にわたり、65 歳以上の高齢者は 69 人 $(40.9 \%)$ あったた「脳血管障害」と「骨・ 関節疾患」は、高齢者の割合が高く、その他の障害は若年者が多い。 「その他の病気」には高齢化による全体虚弱を含む。男性の割合が $56.8 \%$ でった。歩行形態を表 - 7 に示す(注 4 。7 割近くが日常生 活における移動手段として車いすを使っている。

対象者の症状として、運動機能障害によりマヒしている部位及び 視覚障害、聴覚障害、内部障害、知的障害・疾呆の別を障害原因こ とに表ー8に示す。尚、この中には重複障害者 15 名を含む。重複 の内容は「運動機能障害（右マヒ、左マヒ、下肢マヒ、四肢マヒ）」
表-1 竣工年

\begin{tabular}{|c|c|r|}
\hline 碐工年 & 件数 & \multicolumn{1}{c|}{$\%$} \\
\hline 964 & $\mathbf{2 2}$ & 13 \\
\hline 964 & $\mathbf{5 4}$ & 32 \\
\hline 974 & $\mathbf{2 3}$ & 136 \\
\hline 984 & $\mathbf{2 1}$ & 124 \\
\hline 997 & 12 & 7.1 \\
\hline 不明 & $\mathbf{3 7}$ & 21.9 \\
\hline 合計 & 169 & 100 \\
\hline
\end{tabular}

表 - 5 天井走行 リフト有無

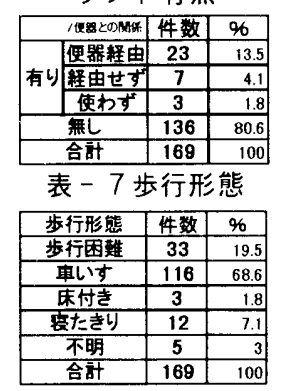

表 - 2 延床面糦

\begin{tabular}{|c|c|c|}
\hline 延床面積 & 件数 & $\%$ \\
\hline EOn未末满 & 4 & 2 \\
\hline 60 80ht末满 & 1 & \\
\hline $80 \sim 100$ 佅满 & 2 & \\
\hline 100 120n佅满 & 10 & \\
\hline 120１400枺满 & 17 & \\
\hline 140１60年末满 & 38 & 22 \\
\hline 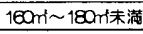 & 33 & 10 \\
\hline $180 \mathrm{~m}^{2}$ 以上 & 64 & 3 \\
\hline 合計 & 169 & $x$ \\
\hline
\end{tabular}

\begin{tabular}{|l|l|l|}
\hline 合計 & 169 & 100 \\
\hline
\end{tabular}

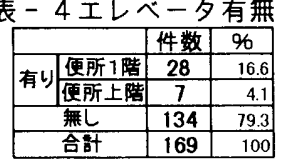

表 - 3 階数

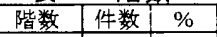
平屋 110 - 59

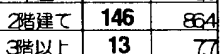
\begin{tabular}{c|c|c|}
\hline 合計 & 169 & 100 \\
\hline
\end{tabular} エエレベータ有無 \begin{tabular}{l|l|r|}
\hline 合部 & 169 & 79.3 \\
\hline
\end{tabular}

\section{表一 6 障害原因と年龄}

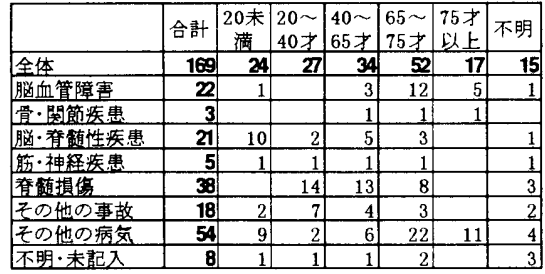

表 - 8 障害原因と症状

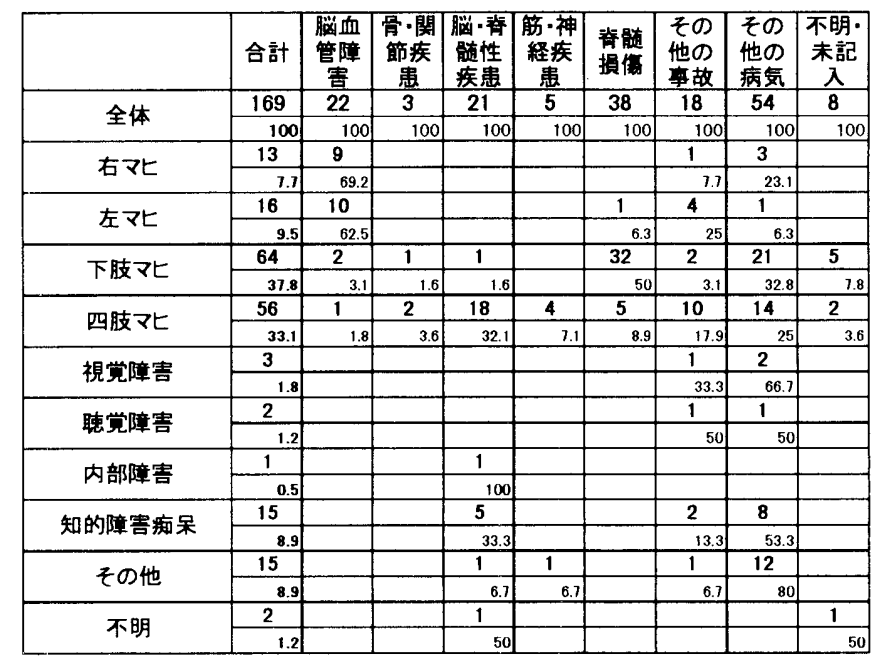

表 -9 障客原因別介助の程度（上段実数、下段\%）

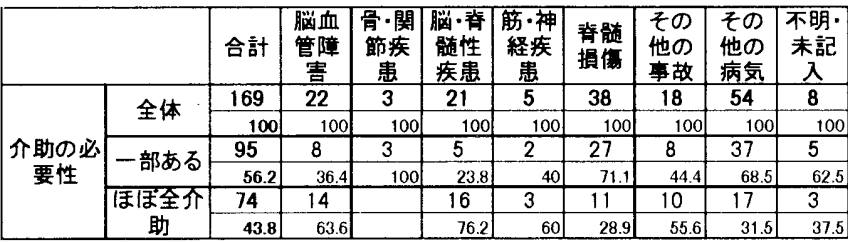

表 - 10 障害原因別介助の有無（上段実数、下段\%

\begin{tabular}{|c|c|c|c|c|c|c|c|c|c|c|}
\hline & & 合計 & $\begin{array}{l}\text { 脑血 } \\
\text { 管噇 } \\
\text { 害 }\end{array}$ & $\begin{array}{c}\text { 骨·関 } \\
\text { 節疾 } \\
\text { 患 }\end{array}$ & 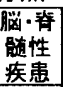 & $\begin{array}{l}\text { 笳·神 } \\
\text { 経疾 } \\
\text { 患 }\end{array}$ & $\begin{array}{l}\text { 等䯣 } \\
\text { 損值 }\end{array}$ & $\begin{array}{l}\text { その } \\
\text { 地の } \\
\text { 事故 }\end{array}$ & $\begin{array}{l}\text { その } \\
\text { 他の } \\
\text { 病気 }\end{array}$ & $\begin{array}{c}\text { 不明· } \\
\text { 未記 } \\
\lambda \\
\lambda\end{array}$ \\
\hline \multirow{2}{*}{ 生活行為 } & \multirow{2}{*}{ 全体 } & 169 & 22 & 3 & 21 & 5 & 38 & 18 & 54 & 8 \\
\hline & & 100 & 100 & 100 & 100 & 100 & 100 & 100 & 100 & 100 \\
\hline \multirow{4}{*}{ 移動介助 } & \multirow{2}{*}{$\begin{array}{c}\Uparrow \text { 助の必 } \\
\text { 要無し } \\
\end{array}$} & 55 & 4 & 1 & 2 & 2 & 16 & 7 & 20 & 3 \\
\hline & & 32.5 & 18.2 & 33.3 & 9.5 & 40 & 42.1 & 38.9 & 37 & 37.5 \\
\hline & \multirow{2}{*}{ 介助必要 } & 114 & 18 & 2 & 19 & 3 & 22 & 11 & 34 & 5 \\
\hline & & 67.5 & 81.8 & 66.7 & 90.5 & 60 & 57.9 & 61.1 & 63 & 62.5 \\
\hline \multirow{4}{*}{ 移乗介助 } & \multirow{2}{*}{$\begin{array}{c}\text { 不助の必 } \\
\text { 要なし }\end{array}$} & 59 & 4 & 1 & 4 & 1 & 20 & 7 & 19 & 3 \\
\hline & & 34.9 & 18.2 & 33.3 & 19 & 20 & 52.6 & 38.9 & 35.2 & 37.5 \\
\hline & \multirow{2}{*}{ 介助必要 } & 110 & 18 & 2 & 17 & 4 & 18 & 11 & 35 & 5 \\
\hline & & 65.1 & 81.8 & 66.7 & 81 & 80 & 47.4 & 61.1 & 64.8 & 62.5 \\
\hline \multirow{4}{*}{$\begin{array}{c}\text { 立ち座り } \\
\text { 介助 }\end{array}$} & \multirow{2}{*}{$\begin{array}{c}\text { 介勖の必 } \\
\text { 要なし }\end{array}$} & 73 & 7 & 3 & 6 & 1 & 16 & 7 & 29 & 4 \\
\hline & & 43.2 & 31.8 & 100 & 28.6 & 20 & 42.1 & 38.9 & 53.7 & 50 \\
\hline & \multirow{2}{*}{ 介助必要 } & 96 & 15 & & 15 & 4 & 22 & 11 & 25 & 4 \\
\hline & & 56.8 & 68.2 & & 71.4 & 80 & 57.9 & 61.1 & 46.3 & 50 \\
\hline \multirow{4}{*}{ 著衣介助 } & \multirow{2}{*}{$\begin{array}{c}\text { 介勛の必 } \\
\text { 要なL }\end{array}$} & 65 & 3 & 3 & 4 & 2 & 18 & 5 & 27 & 3 \\
\hline & & 38.5 & 13.6 & 100 & 19 & 40. & 47.4 & 27.8 & 50 & 37.5 \\
\hline & \multirow{2}{*}{ 介助必要 } & 104 & 19 & & 17 & 3 & 20 & 13 & 27 & 5 \\
\hline & & 61.5 & 86.4 & & 81 & 60 & 52.6 & 72.2 & 50 & 62.5 \\
\hline \multirow{4}{*}{ 用便介助 } & \multirow{2}{*}{$\begin{array}{c}\text { 介助の必 } \\
\text { 要無し }\end{array}$} & 79 & 10 & 3 & 4 & 1 & 23 & 3 & 33 & 2 \\
\hline & & 46.7 & 45.5. & 100 & 19 & 20 & 60.5 & 16.7 & 61.1 & 25 \\
\hline & \multirow{2}{*}{ 介助必要 } & 90 & 12 & & 17 & 4 & 15 & 15 & 21 & 6 \\
\hline & & 53. & $54.5 !$ & & & & 39.5 & 8 & 38.9 & \\
\hline
\end{tabular}


表 -11 障客原因別便所の専用度（上段実数、下段\% )

\begin{tabular}{|c|c|c|c|c|c|c|c|c|c|c|}
\hline & & 合計 & $\begin{array}{l}\text { 脳血 } \\
\text { 管障 } \\
\text { 害 } \\
\end{array}$ & $\begin{array}{l}\text { 骨·関 } \\
\text { 節疾 } \\
\text { 患 }\end{array}$ & \begin{tabular}{|l} 
細·奉 \\
髄性 \\
疾患
\end{tabular} & \begin{tabular}{|l} 
筋·神 \\
経疾 \\
患
\end{tabular} & 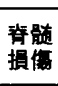 & $\begin{array}{l}\text { その } \\
\text { 地の } \\
\text { 事故 }\end{array}$ & $\begin{array}{l}\text { その } \\
\text { 他の } \\
\text { 病気 }\end{array}$ & $\begin{array}{c}\text { 不明. } \\
\text { 末記 } \\
\text { 入 }\end{array}$ \\
\hline \multirow{2}{*}{\multicolumn{2}{|c|}{ 全体 }} & 169 & 22 & 3 & 21 & 5 & 38 & 18 & 54 & 8 \\
\hline & & 100 & 100 & 100 & 100 & 100 & 100 & 100 & 100 & 100 \\
\hline \multirow{4}{*}{$\begin{array}{c}\text { 軎用の便 } \\
\text { 所 }\end{array}$} & \multirow{2}{*}{ 独立 } & 27 & 4 & & 3 & & $\overline{6}$ & 3 & 10 & 1 \\
\hline & & 16 & 18.2 & & 14.3 & & 15. & 16.7 & 18.5 & 12.5 \\
\hline & \multirow{2}{*}{ 特室通路 } & 49 & 8 & & 6 & 3 & 20 & 2 & 10 & \\
\hline & & 29 & 36.4 & & 28.6 & 60 & 52.6 & 11.1 & 18.5 & \\
\hline \multirow{2}{*}{\multicolumn{2}{|c|}{ 家族と共用 }} & 86 & 10 & 3 & 11 & 2 & 12 & 10 & 33 & 5 \\
\hline & & 50.9 & 45.5 & 100 & 52.4 & 40 & 31.6 & 55.6 & 61.1 & 62.5 \\
\hline \multirow{2}{*}{\multicolumn{2}{|c|}{ 便所を使わない }} & 7 & & & 1 & & & 3 & 1 & 2 \\
\hline & & 4.1 & & & 4.8 & & & 16.7 & 1.9 & 25 \\
\hline
\end{tabular}

表 -12 便所面積と大便器以外の設備機器

\begin{tabular}{|c|c|c|c|c|c|c|c|c|}
\hline & 合計 & $\begin{array}{c}2 m^{2} \text { 末 } \\
\text { 满 }\end{array}$ & $\begin{array}{l}2 \sim \\
25\end{array}$ & $\begin{array}{c}2.5 \sim ~ \\
3\end{array}$ & $\begin{array}{l}3 \sim \\
3.5\end{array}$ & $\begin{array}{c}3.5 \sim \\
4\end{array}$ & $4 \sim 6$ & $\begin{array}{c}6 \mathrm{~m}^{2} \text { 以 } \\
\text { 上 }\end{array}$ \\
\hline 全体 & 169 & 6 & 21 & 12 & 47 & 11 & 52 & 13 \\
\hline 小便器 & 8 & & & 1 & 2 & 1 & 4 & \\
\hline 洗面器 & 52 & & & 2 & 7 & 2 & 30 & 11 \\
\hline 污物流 & 23 & & & & 1 & 3 & 15 & 4 \\
\hline 洗觀機 & 12 & & & & & & 5 & 7 \\
\hline 移莱台 & 3 & & & & & & 3 & \\
\hline 浴楎 & 1 & & & & & & & 1 \\
\hline 不奛 & 91 & 6 & 21 & 9 & 36 & 6 & 6 & \\
\hline その他 & 1 & & & & 1 & & & \\
\hline
\end{tabular}

表 -13 障害種類別介助スペース（上段実数、下段\%)

\begin{tabular}{|c|c|c|c|c|c|c|c|c|c|c|}
\hline & & 合計 & $\begin{array}{l}\text { 脸血 } \\
\text { 管障 } \\
\text { 害 }\end{array}$ & $\begin{array}{l}\text { 骨·関 } \\
\text { 節疾 } \\
\text { 患 }\end{array}$ & 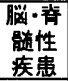 & \begin{tabular}{|c|} 
笳-神 \\
経疾 \\
患 \\
\end{tabular} & $\begin{array}{l}\text { 脊䯣 } \\
\text { 損侄 }\end{array}$ & $\begin{array}{l}\text { その } \\
\text { 他の } \\
\text { 亭故 }\end{array}$ & $\begin{array}{l}\% の \\
\text { 他の } \\
\text { 病気 }\end{array}$ & $\begin{array}{c}\text { 不明. } \\
\text { 末記 } \\
\text { 入 }\end{array}$ \\
\hline \multirow{2}{*}{\multicolumn{2}{|c|}{ 全体 }} & 169 & 22 & 3 & 21 & 5 & 38 & 18 & 54 & 8 \\
\hline & & 100 & 100 & 100 & 100 & 100 & 100 & 100 & 100 & 100 \\
\hline \multirow{2}{*}{\multicolumn{2}{|c|}{ 前のみ }} & 22 & 2 & 1 & 3 & 1 & 2 & 4 & 9 & \\
\hline & & 13 & 9.1 & 33.3 & 14.3 & 20 & 5.3 & 22.2 & 16.7 & \\
\hline \multirow{4}{*}{ 片側と前 } & \multirow{2}{*}{ 右のみ } & 48 & 9 & 1 & 5 & & 12 & 3 & 15 & 3 \\
\hline & & 28.4 & 40.9 & 33.3 & 23.8 & & 31.6 & 16.7 & 27.8 & 37.5 \\
\hline & \multirow{2}{*}{ 左のみ } & 50 & 5 & 1 & 6 & 1 & 9 & 5 & 20 & 3 \\
\hline & & 29.6 & 22.7 & 33.3 & 28.6 & 20 & 23.7 & 27.8 & 37 & 37.5 \\
\hline \multirow{2}{*}{\multicolumn{2}{|c|}{ 両㑡と前 }} & 42 & 6 & & 6 & 3 & 15 & 3 & 9 & \\
\hline & & 24.9 & 27.3 & & 28.6 & 60 & 39.5 & 16.7 & 16.7 & \\
\hline \multirow{2}{*}{\multicolumn{2}{|c|}{ 便所を使わない }} & 7 & & & 1 & & & 3 & 1 & 2 \\
\hline & & 4.1 & & & 4.8 & & & 16.7 & 1.9 & \\
\hline
\end{tabular}

と「知的障害・疾呆」が 12 名（うち「視覚障害小「聴覚障害小「内 部障害」を併せ持つケースをそれそれ 1 例ずつ含む)、「左マヒ」と 「視覚障害」と「聴覚障害」が 1 名、重複している障害名が不明な 対象者が 2 名であった。

2 )介助の程度／生活の全てに介助が必要な対象者が $43.8 \%$ 、部に介助を要する者が56.2\%であった（表－9）。個々の生活行為 の介助必要性の有無について表－10に示す。これらの介助の必要 性の有無に関して、各生活行為間に相関は見られなかった。

・移動時の介助の必要性 : $32.5 \%$ が移動時の介助を不要としてい る。ただし、このなかには介助が不要としながらも、寝たきりで全 く動かない対象者が 2 名含まれている。なお、前述したように天井 走行リフトを用いて便器に移動する例は 23 件であった。

・移乗時の介助の必要性 : 車いす等からベッド、便器への移動に関 しては $65.1 \%$ ガ助を要する。

・立ち座り時の介助の必要性 : 便器やイスでの立ち座りに関しては $56.8 \%$ が介助を要する。

・着脱衣時の介助の必要性：衣服の脱き着に関しては $61.5 \%$ が 助を要する。

- 用便時の介助の必要性 : 排泄中の姿勢保持や後始末、便器洗浄等 に関しては $53.3 \%$ 介助を要する。

\section{(3)便所の配慮設計项目}

介助の必要性が存在すると便所や浴室の計画ではかなり余裕を 持った設計を行うことになる。本研究では、調查対象として介助が 必要な障害者の居住を考虑した住宅の便所としたことと、新築住宅 に限ったことから、面積的に広く設備の充実した実施例が多いとい う調查結果になった。
1) 専用便所の設置／対象者専用の便所を設けている例は 76 件有 り、そのうち 49 件が浴室等の他の部屋に移動する際に経路となる 便所である。便所として独立している例は 27 件である（表 - 11）。 対象者専用とせず家族と兼用する便所に配慮設計を施している例は 86 件である。

2) 便所の広さ／最小寸法は間口（主たる出入り口が有る側）1.5 $\mathrm{m} \times$ 奥行き $1 \mathrm{~m}$ (壁中心 ; 以下同じ) であった。最大寸法は間口 3.5 $\mathrm{m} \times$ 奥行き $2.5 \mathrm{~m}$ で面積が $8.8 \mathrm{~m}^{2}$ あ゙る。 $3 \mathrm{~m}^{2} \sim 3.5 \mathrm{~m}$ の占める割 合が高い(表-12)。

3)排泄以外の用途／便所内に設置している大便器以外の設備機器 を調べた。対象者用洗面器を併設している例が52 件、污物流し又 は洗濯槽を装備している例が 23 件であった。 $4 \mathrm{~m}^{\mathrm{R}}$ 以上の便所では 洗濯機を置く例も見られ（12 件)、浴槽を設けた例もある（表 $-12 ） 。$ 4 )介助スペース／介助スペースの有無は、便器の外縁から壁まで の距離が概ね $500 \mathrm{~mm}$ 以上るか否かで判断した。実際の評価作業は 壁位置を調べて行い、便器側方では便器中心線から壁位置が $750 \mathrm{~mm}$ 以上、便器前方は便器長手方向の寸法として $1400 \mathrm{~mm}$ 以上した。 便器前方だけにスペースがあるということは、実兵上の介助スペー スが無い状態といえ、22 件が該当した。便器右側（洋式便器に座っ たときの右側）にのみ介助スペースを有する例は 48 件、うち 5 件 は出入り口を開けることで介助スペースとなるように設計されてい る。便器左側 (同、左側) のみは 50 件で同じく出入り口の扉の開 放で 2 件が介助スペースを得るようになっている。左右に介助ス ペースを設けた例は 42 件でこの場合はどちらも 18 件ずつが出入り 口の開放によって介助スペースとして利用できる設計としていた。 5 ) 出入りロ／主たる出入り口の開閉方式は引き户が73.4\%であ る。アコーディオンドアや開き戸の吊りもとが移動する事で開閉軌 跡が小さくなる特殊な建具を利用している例があった。

6 )接続する部屋・空間／便所に接続する空間は廊下がもっとも多 く、約半数の便所が廊下からのみ出入りできる計画であった。寝室 に直結して直接行き来できる例は 64 件有り、浴室や廊下等の他の 部屋・空間への経路となるプランも見られた。また、居間や洗面所 に接続しているプランもあり、他の部屋・空間との接続の仕方によ り以下に示す 9 通りの組み合わせに分類できた。尚、寝室とは対象 者が使用する寝室とする（以下同じ）。

・寰室との間にのみ出入り口がある

・廊下との間にのみ出入り口がある $\rightarrow$ 廊下付属夕イプ

・洗面所との間にのみを出入り口がある $\rightarrow$ 洗面所付属夕イプ

・寝室との間及び浴室との間に出入り口がある $\rightarrow$ 寝室浴室間夕イプ ・嵔室との間及び廊下との間に出入り口がある ・富室との間及び浴室との間及び廊下との間に出入り口がある

$\rightarrow$ 寝室浴室廊下間タイオ

・廊下との間及び洗面所との間に出入り口がある

$\rightarrow$ 廊下洗面所間タイプ

・廊下との間及び浴室との間に出入りロがある $\rightarrow$ 廊下浴室間タイプ ・寝室との間及び洗面所との間に出入りロがある

$\rightarrow$ 㷃室洗面所間夕イフ

分類された 9 夕イプの特徵を表ー 14 に、設計例を図ー1に示す。 上記のタイプ以外では居間や食堂等から直接出入りする例も見ら れたが、それらは「その他」として分類することとした。また、便 
表 -14 接続する部屋・空間から分類した各タイプの特徵

\begin{tabular}{|c|c|c|c|c|c|c|c|c|c|c|c|c|c|}
\hline \multirow[b]{2}{*}{ タイプ } & \multirow[b]{2}{*}{ 㓞断基準 } & \multirow[b]{2}{*}{ 件数 } & \multicolumn{5}{|c|}{ 接緒する部屋·空間 } & \multicolumn{2}{|c|}{ 便所の尊用度 } & \multirow{2}{*}{\begin{tabular}{c|} 
抹泄以 \\
外の用 \\
途 \\
\end{tabular}} & \multirow{2}{*}{ 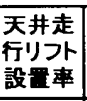 } & \multirow{2}{*}{ 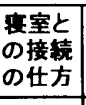 } & \multirow{2}{*}{$\begin{array}{l}\text { 介助ス } \\
\text { ペース }\end{array}$} \\
\hline & & & 事室 & 席下 & 洗面所 & 浴室 & その他 & 轀用 & $\begin{array}{c}\text { 家禁共 } \\
\text { 用 }\end{array}$ & & & & \\
\hline 1)衰室付属タイプ & \begin{tabular}{|l|} 
寝室との間にのみ出入りロがあ \\
る
\end{tabular} & 22 & - & & & & & - & & & 高 & 直結 & \\
\hline 2)席下付属タイプ & \begin{tabular}{|c|} 
廊下との間にのみ出入りロがあ \\
る \\
\end{tabular} & 81 & & - & & & & & $\bullet$ & & & & \\
\hline 3)洗面所付属タイプ & \begin{tabular}{|c|} 
洗面所との間にのみ出入り口が \\
ある
\end{tabular} & 3 & & & - & & & & - & $\begin{array}{c}\text { 便所の } \\
\text { み }\end{array}$ & & & \\
\hline 4)主室浴室間タイプ & \begin{tabular}{|c|} 
疫室との間及び浴室との間に出 \\
入りロがあ
\end{tabular} & 16 & - & & & 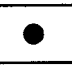 & & 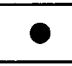 & & $\begin{array}{l}\text { 洗面·脱 } \\
\text { 衣空 } \\
\end{array}$ & 高 & 直䊅 & 両側 \\
\hline 5)衰室廊下間タイプ & \begin{tabular}{|c|} 
疫室との間及び廊下との間に出 \\
入りロがある \\
\end{tabular} & 4 & 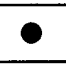 & 0 & & & & • & & & & 直銡 & \\
\hline 6)春室浴室店下間タイプ & 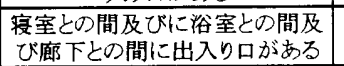 & 13 & - & - & & - & & 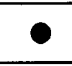 & & \begin{tabular}{|c|} 
洗面·脱 \\
衣室 \\
\end{tabular} & 高 & 直結 & 両側 \\
\hline 7)廊下洗面所間タイプ & $\begin{array}{c}\text { 廊下との間及び洗面所との間に } \\
\text { 出入がる }\end{array}$ & 3 & & $\bullet$ & - & & & & $\bullet$ & \begin{tabular}{|c|} 
便所の \\
2
\end{tabular} & & & \\
\hline 8)席下浴室間タイプ & \begin{tabular}{|c|} 
廊下との間及び浴室との間に出 \\
入りロロがあ \\
\end{tabular} & 5 & & • & & - & & & - & \begin{tabular}{|c|} 
洗面·脱 \\
衣室 \\
\end{tabular} & & & \\
\hline 9)表室洗面間タイプ & \begin{tabular}{|c|} 
寝室との間及び洗面所との間に \\
出入え゙る
\end{tabular} & 9 & - & & - & & & • & & & & 直䊅 & 両側 \\
\hline その他 & 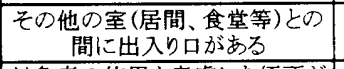 & 6 & & & & & $\bullet$ & & - & & & & \\
\hline 更斥を使わない & \begin{tabular}{|c|} 
対象者の使用を考虑した便所が \\
ない
\end{tabular} & 7 & & & & & & & & & & & \\
\hline
\end{tabular}

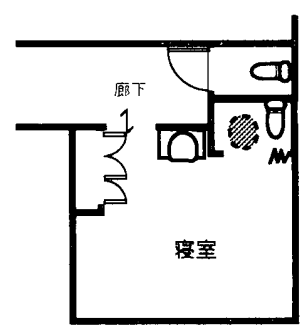

5)寝室廊下間タイプ
1)寝室付属タイブ

2)廊下付属タイプ

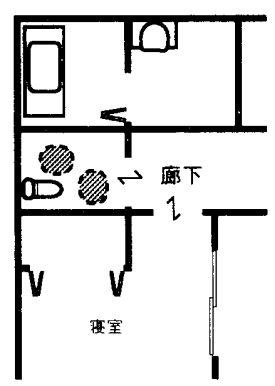

6) 寝室浴室廊下 間タイブ

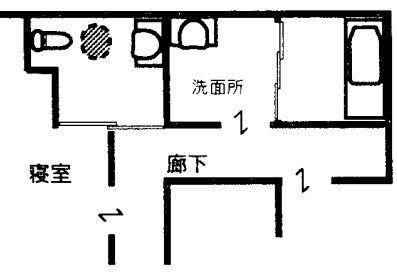

旅: 介助スペースを示す (幅 $60 \mathrm{~cm} 、$ 高さ $50 \mathrm{~cm}$ )

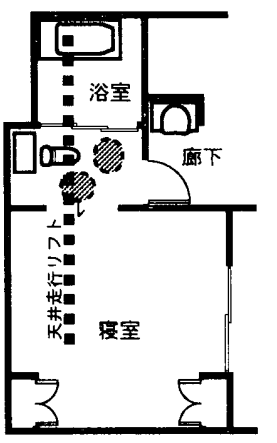

3)洗面所付属タイプ

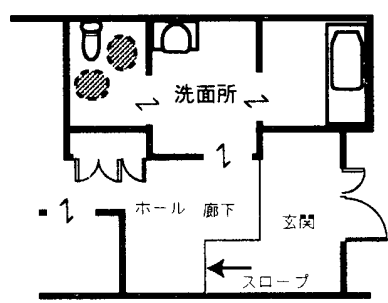

7) 廊下洗面所 間タイプ

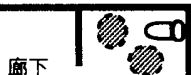

$-1 \div 1$

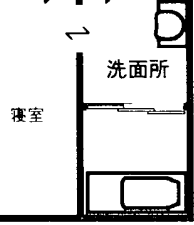

4)寝室浴室間タイプ

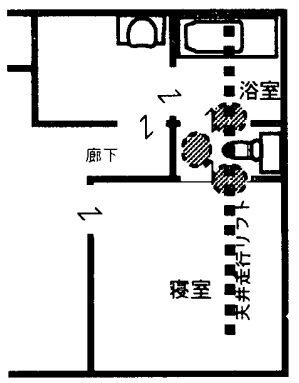

9)寝室洗面所 間タイブ

\section{図 - 1 便所タイプ別の設計例}

所を全く使わないで排泄するケースが7例見られた。主に寝たきり で、座位姿勢を保持できず、かつ、自力で排泄することが不可能な グループで、おむつ等を使用して排泄するものと思われる。新筑時 で十分な設計配慮ができるにも関わらず、便所内での排泄をあきら めているということであり、建築的配慮だけでは対処できない身体 的状態等、種々の状況の存在をうかがわせる。

\section{4、接続する部座から見た便所空間分析}

表-15〜表-18にそれそれ便所タイブことの対象者の障害原 因、歩行形態、介助程度、便所面積 ・介助スペースの位置、便所内 設置設備機器、天井走行リフトの採用状況を示す。これらから各夕 イプごとの特徵と計画時に留意す心゙き問題を述べる。尚、表 -19 に
便所タイプ別延床面積を参考として示す。延床面積は家族構成等の 他の要因の影響を受けると思われる。ここでは、介助の必要性が高 いために設けた離れと推測できる小規模住宅において浴室と接続す るタイプが多かったと記述するにとどめたい。

(1)各タイプの特徽と計画上の留意点

1)寝室付属タイプ／寝室から直接行き来できる対象者専用の便所 である。障害原因別での採用の割合には大きな特徵が見られない。 介助程度ではやや全介助者の割合が少ない。便所面積では $2 \mathrm{~m}$ 以下 の狭小な例が見られる。これは寝室と一体で使えるためと思われ る。要全介助者の割合は他のタイプと比べて多いと言えないが、 図-1に示した例のように寝室との間の壁を全て開口部として介助 のしやすさをは向上させたケースもある。洗面器を設けて洗面所を 
表 - 15 便所タイプ別対象者の障害原因（上段実数、下段\%）

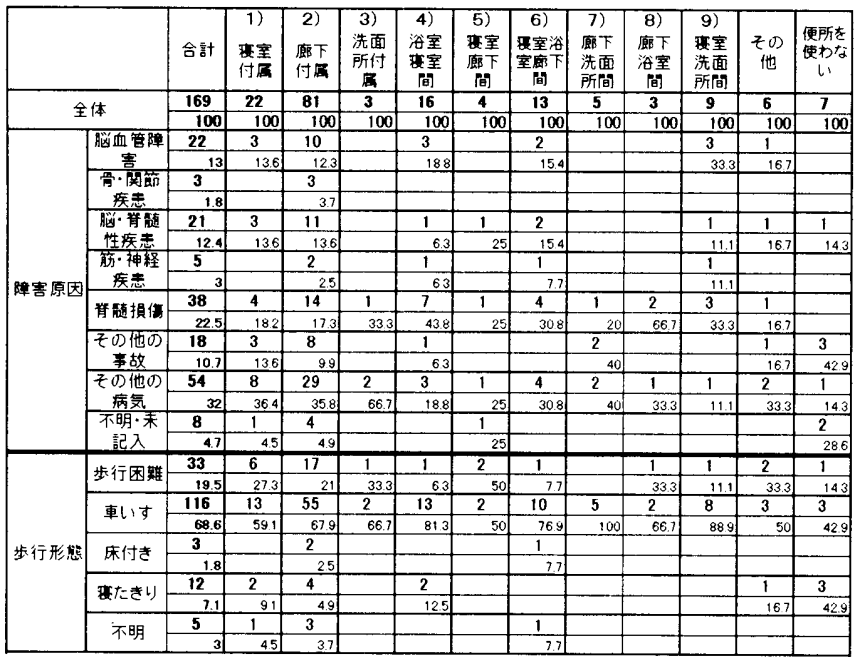

表 -16 便所タイプ別介助程度（上段実数、下段\%)

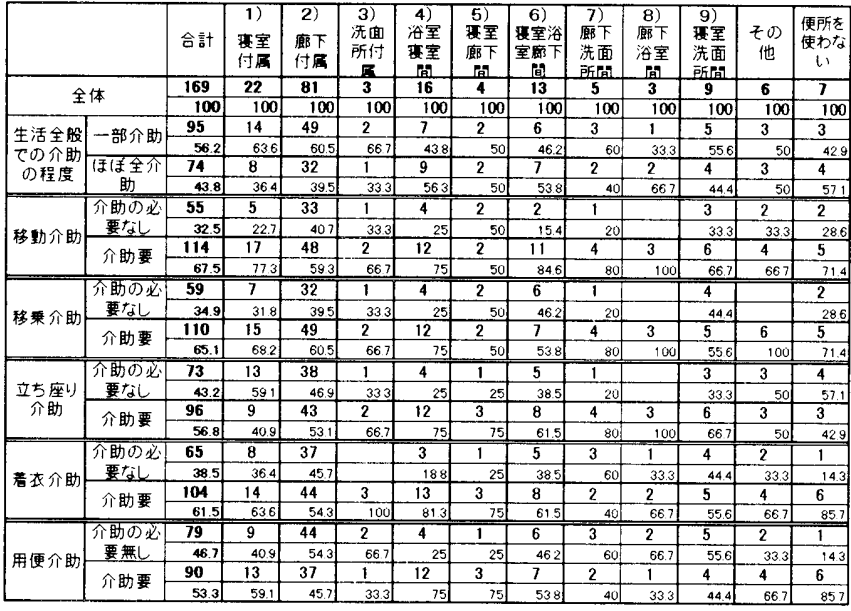

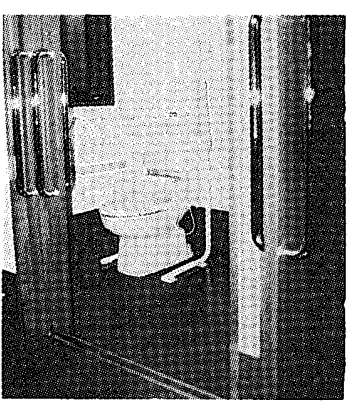

図一 2 廊下付属タイプ例

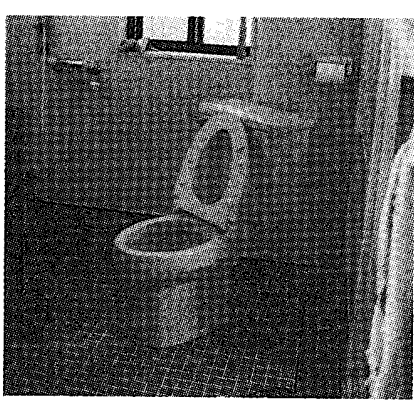

図ー 3 寝室浴室間タイプ例
兼わるプランが 3 割以上 $(8 / 22$ 、該当件数/タイプの総数を示 す。以下同じ）みられた。洗濯槽（污物流し含む。以下同じ）の設 置も 2 割以上 $(5 / 22)$ あった。寝室と直結したタイブに共通す る利点として、下着の脱き着を寝室内で行える点と急激な温度変化 等が生じにくい点があげられる。ベッドからの便器までの距離が短 くなることからも、自立生活の促進をはかる目的も有するものと思 われる。反面、閉じられた空間になるので、事故等が起きたときに その発生が伝わりにくいことが考えられる。

2 ) 廊下付属タイプ／廊下からのみ出入りできる独立した便所で、 一般住宅にもっとも普通に見られるタイプである。本調查の約半数 の 81 件がこのタイプであり、間口を広げて介助空間を確保してい る例が多く見られた。便所面積は、約 2/3(55/81) が $3 \mathrm{nn}^{2}$ 以 上である。洗面器を設置して洗面所と兼用している例は 13 件だっ
表 -17 便所タイプ別便所面積・介助スペース（上段実数、下段\%）

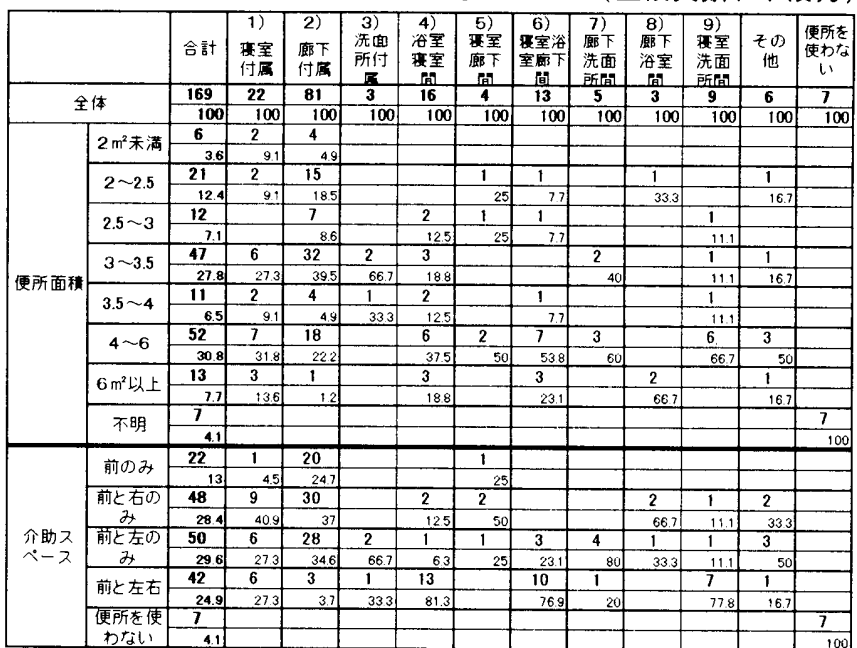

表 -18 便所タイプ別大便器以外の設備機器·天井走行リフト
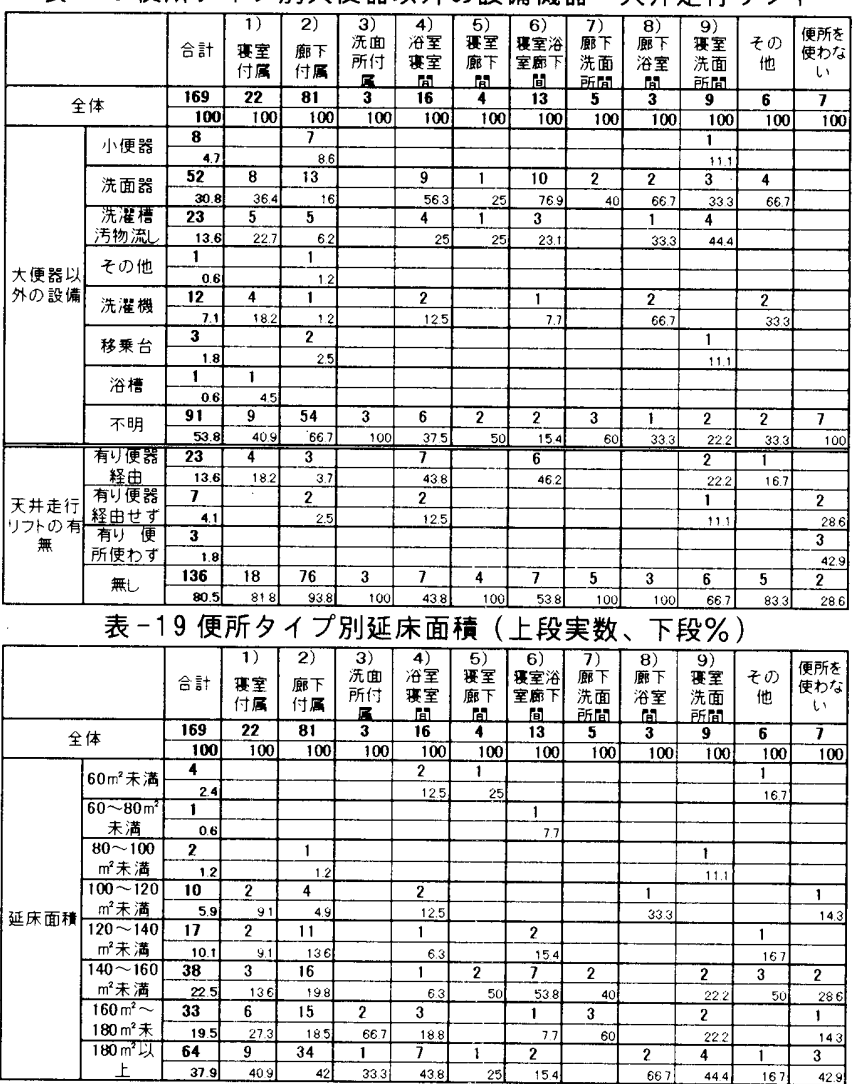

た。このタイプはほとんどの場合家族と共用している（図－2）。 3)洗面所付属タイプ／洗面所の奥にあり、洗面所を経由してのみ 出入りできる。本調查では実数が少なかった。家族と共有する場合 が多い。洗面所の空間を車いす操作空間として利用でき、便器に対 してアプローチしやすい。出入りロの郝を開放して洗面所とワン ルームとする使い方ができる利点が考えられるが、出入りのために 建具操作が增えるといった点では不利である。建具が開閉時に千涉 しないような計画が望まれる。

4) 寝室浴室間タイプ／寝室から浴室へ行く経路上に便所が位置す るタイプで、要介助者専用の脱衣空間としても利用される。春椎損 傷者を含む車いす使用者の割合が高く、全介助の必要性も高い。萝 室及びサニタリー諸設備機器に最短距離となり、介助の程度が重い 場合には特に有効と思われる。排泄に失敗した場合にも被介助者の 
体を洗いやすいという利点も考えられる。天井走行リフトを設置す る場合の標準的な計画ともいえ、本調査では、半数以上 $(9 / 16)$ において天井走行リフトが設置されていた。一般的に寝室と便所と 浴室が直線上が計画され、天井走行リフトのレールに沿うように ベッドと便器、浴槽が配置されている。介助スペースに関しては、 左右両側に確保されているケースが 8 割以上 $(13 / 16)$ と多かっ た。特に天井走行リフトを設置した計画では、便器の両側（寝室側 と浴室側）に出入り口が設置されるケースがほとんどであり、扉を 開放することで最小寸法ながら介助可能としている（図－3）。ま た、半数以上 $(9 / 16)$ が、他の用途として洗面器を設置してい た。洗濯槽を設置した例も 4 件あった。

計画にあたって、浴室からの湿気が寝室に進入しないように防止 策を検討する必要がある。

5)寝室廊下間タイプ／寝室と廊下の両方から出入りできる。要介 助者専用便所に多く、日中、居間などの寝室外で時間を過ごす場合 に、別の経路として設けていることが多い。

車いすを使う場合は便器に接近する方法が重要であるが、この夕 イプは出入り口の位置が異なるため、便器の向きと出入り口の関係 を調整しなければならない。

6) 葠室浴室廊下間タイプ，上記 4)のタイプに廊下側の出入りロ を追加している。歩行形態では約 8 割 $(10 / 13)$ が車いすを使用 していて、各生活動作での介助の程度を見ると全ての動作で介助の 必要度が高いと思われる。便所面積では約 8 割 $(10 / 13)$ が $4 \mathrm{~m}^{2}$ を越え、天井走行リフトの採用も多く(6/13)、介助スペースに 関しても 4 )と同様に 10 件が両側に確保している。約 8 割（10／ 13）が洗面器を備えており、家族の共用の脱衣洗面所を兼ねている とみられる。洗濯槽の設置も3件あった。

家族が浴室を使うため、要介助者には浴室使用時の騒音対策が、 家族を含めた入浴者にとっては良好な温度環境を維持するための気 密性が要求される。

?) 廊下洗面所間タイプ/上記 3 ) 洗面所付属タイプに廊下側の出 入りロを追加している。全員怔車いすを使用していて、各生活動作 で介助の必要度が高いと思われる。このタイブは家族と共用する場 合が多いが、5)と同様、日中の居場所として居間等が考えられ、そ のための介助移動の容易さをはかっているとも推測できる。

複数の出入り口を有する室に共通する問題として、施錠の方法が あげられる。また、照明器具や換気扇のスイッチに関してどちらの 出入り口からでも操作できるようにしなければならない。

8) 廊下浴室間タイプ／廊下から浴室への経路上にあり、家族共用 の脱衣室を兼ねたタイプである。実施例は少ないものの、特徵的な 平面計画である。約 6 割 $(2 / 3)$ のプランで便所の面積が 6 m 以 上あり、脱衣室及び洗面所と兼用して一体で広く使うことを主眼と しているようである。

計画するにあたっては、家族の日常的な入室時に便器が直接目に 入りにくいようにしておきたい。廊下から浴空に至る主動線上から はずして便器を設膡するか、あるいは間仕切りスクリーンのような もので便器を隠す等が考えられる。

9 ) 葠室洗面所間タイプ／寝室から洗面所八の経路上に位置する。 洗面所は浴室と接していて、家族共通の脱衣室として使われている ケースが多い。この場合は 4 )、6) と同様の使い方をされるものと
思われる。面積的には $4 \mathrm{~m}$ を越え、介助スペースも十分左右に確保 している $(7 / 9)$ 。

便所が要介助者の専用空間として確保されているので、プライバ シ一や遮音性あるいは気密性等については4)及び6)の欠点を緩和 するが、住宅全体に対してサニタリー面積の割合が多くなる。

\section{5.おわりに}

介助動作を考慮した住宅における便所設計の平面計画上の特徵を 整理することができた。住宅内で行う介助のために必要な建築的配 慮をさらに明確にするためには、今後の課題として以下の 2 点に関 する調査研究を行いたい。すなわち、1)実際に家庭で行われている 排泄に関わる生活行為、動作の現状、2)施された配慮設計の有効性 に関しての調査であり、前者については、家族による介助動作で あって瞕業的に手慣れた介護、介助動作が期待できないことを考慮 に入れ、また後者では要介助者の障害の進行及び介助者の身体機能 低下等の影響を踏まえて調查すべきと思う。また、これらの調查に 加えて、便所内での介助動作の寸法や壁を支えにした介助方法など の実際的な生活場面での検討も進めたい。

注記 1 : 日本住宅性能基準「高齢者等への配慮に関すること」では 性能を 5 段階の等級に分けている。この数値は $1300 \mathrm{~mm}$ は等級 5 の短辺最小値。等級 4 では短辺の值を小さくし長辺の最小寸 法も指定している。(参考文献 1)

注記 2 : 天井走行リフトとは、天井に固定したレールに吊り上げ機 を設けた移動用福祉機器であり、レールに沿って移動できる。 注記 3 : 障害原因は高山忠雄（当時、国立身体障害者リハビリテー ションセンター研究所）らの分類を元に、「その他の事故」を 加えて用いた（参考文献 3 )。

注記 4 : 脳性マヒ等による四肢マヒ者で床に座った状態で移動する 步行形態を本論文では床付き歩行という単語を用いて表現して いる。本論文でのみ使用していることを付記する。

\section{《参考文献>}

文1）建設省住宅局住宅生産課監修、住宅性能表示制度評価方法基準·技術解説、 工学図書、pp332 345、2000

文2）後藤義明、相良二朗、田中直人ほか、介助動作に必要な便所及び浴室のス ペースに関する実験、日本建築学会計画系論文集第 512 号、pp145～pp152、 1998.10

文3）高山忠雄、在宅高秢障害者の生活支援機器分類とそれに基つくデータバー スの開発に関する研究一昭和 63 年度報告、国立身体障害者リハビリテーショ ンセンター研究所、1989.3

文4）日本障害者協議会編、障害者の生活環境改善手法、彰国社、1994.11

文5）鈴木秀司ほか、高龄者のための住宅改造計画に関する研究、日本建築学会 大会学術講演梗概集 pp241 pp242、1995

文6）森本康代ほか、既存住宅おける住人の高䶖化对応の可能性について、日本 建勧学会大会学術講演梗概集 $p p 175 \sim p p 176 、 1996$

文7）金良英、小滝一正、大原一興ほか、脳卒中患者の病院退院時要因加らみ た住宅改造の目樏設定、日本建築学会大会学術講演梗概集 $\mathrm{pp} 179 \sim \mathrm{pp} 180$ 、 1996

文8）新住宅推進協議会・日本住宅設備システム協会編、改訂版・ケア住宅の計 画、㓱樹社、1997.3

文9)ハンディキャップ者配虑の住宅計画、日本建築学会設計計画パンフレット 27、彰国社、1984.10

文10）古賀唯夫、片岡正喜、村上良知、身体障害者向け特目住宅の住空間構成に 関する研究、その 3 .身体障害者の動作特性からみたサニタリールームの評 価、日本建築学会諭文報告集第 273 号 P79 P86、1978.11

(2000年12月10日原稿受理，2001年6月22日採用決定） 